\title{
In the Shadow of No Memories? The Role of Dementia in Contemporary Aftermath Writing
}

The mechanisms of our metaphorical conceptualisation of dementia have been the subject of extensive scrutiny in recent research at the intersection of neuroscience, sociology and pathography studies. Foregrounding the "range of emotionally charged metaphors about dementia" that "pervades the popular imagination" (Zeilig 2014a, 258) in contemporary Western societies - from the media and political discourse to film and literature but also medico-scientific terminology - current work in this area has been aimed at sensitising us to the assumptions informing the cultural narratives we tell ourselves about this complex of disorders that remains empirically and medically beyond our full grasp. ${ }^{1}$ Particularly in the contact zone between dementia studies and gerontology, significant advances have been made in exploring how the interrelation between social construction and biomedical condition has coloured not only cultural images but also the clinical picture of dementia. In highlighting "the problematic consequences of popular discursive practices that associate dementia with disaster" (Zeilig 2014b, 88) and frame it "as a dread disease and major public health crisis" (Ballenger 2017, 716) in a society on the brink of being overwhelmed by the "apocalyptic demography" (Robertson 1990) of its growing older dependent population, these investigations are contributing in essential ways to an emerging trend in the theory of dementia care away from an emphasis on cognitive and mental deterioration and towards a more embodied approach to notions of subjectivity and personhood. ${ }^{2}$

And yet, running counter to this push for an embodied, decatastrophising approach, an apocalyptically heightened figurative use of dementia in popular culture not only persists but is apparently proliferating to the point where, two decades into the twenty-first century, dementia seems to have come to represent "the locus of and repository for all society's fears” (Zeilig 2014b, 89). Accordingly, while investigations to date have concentrated primarily on the metaphors through which we evoke dementia, a secondary research focus on our invocation of dementia as metaphor is taking shape. The scope of the enquiry is expanding to take

1 See also e.g. Ballenger 2006; Leibing and Cohen 2006; Basting 2009; Behuniak 2011; Swinnen and Schweda 2015; Hartung 2016, Ch. 4; Zimmermann 2017a; Falcus and Sako 2019.

2 See e.g. Higgs and Gilleard 2017.

Ә Open Access. (C) 2022 Kirstin Gwyer, published by De Gruyter. (c) BY-NC-ND This work is licensed under the Creative Commons Attribution-NonCommercial-NoDerivatives 4.0 International License. 
in the growing body of cultural productions where the "only seemingly individual or ahistorical" diseases of dementia, as Krüger-Fürhoff, Schmidt and Vice put it in the introduction (3) to the present volume, are enlisted "to represent or respond to violent historical and political events” and figure dynamics of remembering and forgetting at a collective, societal level.

The focal point of this essay will be the intersection where dementia as a lived reality connects with, and risks being displaced by, dementia as a way of making sense of the world. Through an exploration of the shared fund of imagery used to paint both dementia as an apocalypse and apocalyptic scenarios through dementia, I shall suggest that the metaphorical relationship between the two should in fact be thought of as one of analogical participation rather than simple correlation: though dementia undoubtedly represents a "locus" and "repository" of societal fears (Zeilig 2014b, 89), they are fears that feed on, and feed into, a greater and more complex set of cultural anxieties. The images we use to think about dementia, often in the synecdochal figure of Alzheimer's disease, point to "the biomedical aspects of the condition that are most dreaded by society” (Zimmermann 2017b, 74), chief among them "the patient's dependence, inertia, and loss of self" (90). However, our use of dementia as an image suggests that the constellation of memory erosion leading to a loss of self and sense of inertia also resonates with us in more general and abstract terms, through what it captures about our perception of our own present reality. Drawing on examples from current popular and scientific practice, as well as from two representatives of recent post-trauma fiction, where dementia is commonly invoked as a theme and trope, I will propose that the 'dementia turn' we observe in contemporary literature, film and comics may be understood as an illustrative paradigm for a far broader cultural sense in which neoliberal global-capitalist societies experience themselves as existing in a twilight zone of (post-genocidal, post-conflict, postcolonial, post-nuclear, post-terrorism) post-traumatic aftermath, wracked with "mnemonic convulsions" but "terminally ill with amnesia" (Huyssen 1995, 7, 1). In this twilight zone, the amnesiac state diagnosed by Huyssen at the end of the twentieth century is increasingly acutely experienced as a degenerative condition at once irremediable and inexorable, without hope for either retrospective or prospective recuperation.

\section{Figuring dementia}

Studies investigating the metaphorical evocation of dementia have noted a prevalence of doomsday imagery centred on natural disasters, disease or other 
cataclysms of biblical proportions across both popular and scientific discourses. ${ }^{3}$ Dementia is the "quiet epidemic" (Wilson 2014), the "21st century plague" (Smyth 2013) or "leprosy of the early 2000s" (Behuniak 2011, 84), a "rising tide" and "silent tsunami” (qtd. in Zeilig 2014a, 260). Sometimes, the scourge is by flame rather than flood: "a story of hell," of being ravaged by a "forest fire," by "the holocaust of my brain" (qtd. in Zimmermann 2017b, 83, 85, 82). Dementia is conceptualised as "a lethal threat at both the individual and social levels" (Behuniak 2011, 85), and its carriers - "zombies," the "living dead," the "grey hordes" $(77,79)$, members of the “apocalyptic demography” (Robertson 1990) - are coming for us. In response to the perception of dementia as a silent but devastating threat, the other semantic field to have been identified as dominating popular rhetoric in the West is the language of "military and war-like metaphors" (Zeilig 2014b, 85). In this rhetoric, dementia is a "killer" (Zeilig 2014b, 84), requiring an "all-out fight-back" (qtd. in Zeilig 2014a, 261), or even - suffused with the righteous conviction of waging a holy war - a "millennium demon" calling for a "crusade" (qtd. in Zeilig 2014a, 260).

However, although it is not unusual for calls for the eradication of a pernicious disease to be couched in the language of warfare - as with HIV/AIDS or cancer - the twist where dementia is concerned is that the militaristic language it elicits tends to be more closely related to the experience of being under siege, taken hostage or hijacked in ways that seem informed not by war in general but by underlying cultural anxieties about specifically terrorist warfare. The image of the "time bomb" recurs frequently, gesturing towards "politically motivated terrorism” (Zeilig 2014a, 261). Susan Schneider Williams (2016), whose late husband, actor Robin Williams, had Lewy body dementia, refers to "the terrorist inside my husband's brain,” sending “a firestorm of symptoms our way” (1308) and leaving him "trapped in the twisted architecture of his neurons" from which she "could not pull him out" (1309). Even the image of the "crusades" to fight the "millennium demon" has acquired a secondary metaphorical frame following the repeated contentious invocation of crusader history after 9/11, in the context of George W. Bush's global "war on terror."4

The convergence of apocalyptic zombification and terrorism that emerges from these images is troubling yet telling. As an attempt to evoke the lived reality of a condition, the yoking together of the figure of dementia as a terrorist who takes control of a hostage's brain to leave them "like a 747 airplane coming in with no landing gear” (Schneider Williams 2016, 1309) and of the ghoulish

3 See e.g. Innes 2009; Zeilig 2014a; also Martina Zimmermann's contribution to this volume.

4 See e.g. Johnsrud 2017. 
visions of walking death, of a "living body without a mind" (Gerritsen et al. $2018,599)$ is profoundly problematic. As Susan Behuniak has shown with specific reference to the Alzheimer's variant of dementia, "the social construction of those with $\mathrm{AD}$ as zombies generates not only the negative stereotypes and stigma associated with people constructed as 'other,' but also the emotional responses of disgust and utter terror” (2011, 72). However, as in earlier incarnations of the runaway zombie metaphor as an evolving receptacle for Western fears for going on a century, the metaphor of the undead reveals far more about the cultural context in which it is figuratively deployed than about the object to which it is temporarily attached.

Since the figure's initial appropriation from Vodou culture and its application to the bare life of slave labourers in US-occupied Haiti in the 1920s, zombies in the Western imagination have been associated with everything from the Second World War, National Socialism, concentration camp inmates, the threat of communism and nuclear destruction, race relations, the Vietnam War, capitalist brainwashing and mindless consumerism, pandemics including AIDS and Ebola, and the viral spread of information in the mass media to, more recently, globalisation and mass migration, postcolonial or urban-proletarian rage, and terrorism. ${ }^{5}$ The indeterminacy of the image becomes apparent from even this incomplete list. Indeed, indeterminacy might be considered the defining feature of the modern-day zombie, for the one thing that all its recent manifestations have in common is how difficult they make it to locate the perceived threat they are meant to embody. Before they are infected, and sometimes even afterwards, contemporary zombies look just like the next person, and anybody could be one. This is also where the metaphor's connection to acts of domestic or clandestine terrorism is clearly in evidence: "Like the 'sleeper-cell' terrorist, the zombie can potentially be anyone" (Muntean and Payne 2009, 247). In consequence, "as with the friendly suburban foreign students-cumterrorists of 9/11," the "inside/outside or us/them differentiation breaks down" (Schmeink 2016, 221), and "fear and terror emerge from the possibility of becoming a victim at any time" (210). ${ }^{6}$

A similar sense of the self/other separation not holding also informs contemporary views of dementia. Societally but even medically, it is conceived as a set of conditions that could not only affect anyone at any time, but which 'contaminate' those 'exposed' to them long before they develop any active form of the syndrome themselves. At a societal level, this arises in part from our tendency to

5 See Luckhurst 2016 for a comprehensive cultural history of the figure of the zombie. On specifically the figure of the zombie terrorist, see, e.g. Edwards 2015.

6 See Stratton 2011 for a further striking example of indeterminacy in the figure of the zombie for displaced persons perceived as a threat to the neoliberal state. 
conflate dementia with ageing and to think of it as a looming horizon worse than death. It also manifests itself in the perception that "the time and lives of caregivers and family members are consumed by the disease" alongside those of the primary sufferers (Behuniak 2011, 82). Both conflations derive their sense of dread from the unacknowledged understanding that zombies are not just among us but are us, or that we are them. ${ }^{7}$

More recently, the phenomenon of "collateral contamination" has also become a focus of scientific research investigating the "senescent-cell bystander effect" in dementia-related conditions and conceptualizing this as a zombie attack: "The emergence of senescent neurons means the AD brain contains zombie-like cells that kill healthy bystander neurons. We do not know what creates the zombies, but to fully treat AD they must be destroyed. This presents a paradox: to cure a neurodegenerative disease, we have to kill more neurons" (Chow et al. 2016, 658). Presented under the subtitle "The Continuing Saga of the Zombie Apocalypse" and condensing imagery of a zombie contagion with the arbitrariness of a terrorist strike taking out innocent 'healthy' bystanders and prompting murderous retaliatory violence, this makes for uncomfortable reading, even though - or precisely because - the article's reference to "zombie cells" is fully in keeping with scientific practice. ${ }^{8}$

Though the process of 'senescence-inducing senescence' is not exclusive to dementia-related neurodegeneration, its association here with zombified mindlessness and its illustration as a form of infiltration by something that is already there, like sleeper cells in our brains, connects with and risks fuelling the popular reading of dementia as a disease that can, and given enough time will, happen to anyone and to which any of us, unwittingly, may already be a 'host.' As Chow et al. (2016) suggest, in their subtitle's reference to a continuing saga (though their suggestion of a 'full treatment' partially obscures this), the zombie apocalypse is already underway in this scenario, and, while the end of the world has been delayed, its ultimate arrival remains always on the horizon. In the absence of an identifiable cause for the zombies' emergence, the destruction of subsequent neurons under zombie attack remains for now a (hypothesised) postponement of the inevitable rather than a 'cure' - or at least a cure that would be distinguishable from annihilation. It offers neither resolution nor prevention, just deferral.

Viewed narrowly in terms of the fears it communicates about human neurohealth in an ageing society, this sense of living in deferment reads as a sort of

7 See also Behuniak 2011, 79, on this point.

8 See also, e.g., the more recent, more neutrally worded, Bussian et al. 2018. 
generalised, prognostic equivalent of what Arthur Frank has termed the "remission society" (2003 [1995], 8). Rather than life in limbo between disease and cure, where survivors become the walking wounded, it seems to denote existence in an aftermath of (self-)diagnosis but before full-blown (and fatal) morbidity, turning us all into the walking dead. However, as the second part of this essay will propose, the convergence of dementia and zombifying cataclysm suggests that our sense of living in apocalyptic latency extends well beyond the concrete context of dementia as a neurological syndrome. A closer look at Schneider Williams's dementia-as-terrorist pathography at the intersection of scientific and popular discourse and of medical report and literary rendition, where figurative evocation of dementia meets the invocation of dementia as a figure, will serve to illustrate this, before I move on to examine the reverse aspect of the material discussed so far: the use of dementia as a metaphor for living in a latent apocalypse.

\section{Dementia as figure}

Schneider Williams's use of the figure of a terrorist plane hijacking articulates a cataclysmic personal event that defies comprehension through the figure of another, the culturally specific but broadly accessible reference point of 9/11. It is a shorthand for devastation and an attempt to mentalise the unimaginable. At the same time, it is also a way of acknowledging changes in her late husband's behaviour without holding him, the hijacking victim, responsible. Through no fault of his own, Williams, once her "safe harbor" (Schneider Williams 2016, 1308), is now exuding threat: his is the brain left in ruins, the "twisted architecture" (1309) in which he becomes trapped after the "firestorm of symptoms" (1308) hits, but he is also the plane being steered towards impact. In this respect, the terrorist imagery also captures the breakdown of the inside/outside and self/other distinction that is believed to characterise the disease: dementia terrorises because what feels like a hostile external invader turns out to be a clandestine fifth column already at home in the host, and it torments not just the primarily afflicted but also those who care for them. Inasmuch as the "firestorm of symptoms" hits both spouses, it also represents a "traumatic experience" for Schneider Williams herself, as she is vicariously exposed to "persecution" (1308) by the disease's pathology and feels as if she is "drowning” in Williams's symptoms "along with him" (1310). In the wake of the "firestorm," she is left "powerless and frozen," "in the darkness of not knowing" (1309) and with an enduring sense of living in suspended time, as she is compelled to go over and over the same old ground: "After Robin left, time has never functioned the same for me. 
My search for meaning has replicated like an inescapable spring” (1310). Her experience of the aftermath of her husband's illness and death bears the hallmarks of PTSD, including a sense of stasis and meaninglessness, dissociation and compulsive repetition. However, the language used to evoke this echoes descriptions of Williams's dementia, of his being "stuck in a frozen stance" (1309) where he feels "blank" and "lost in confusion" and experiences persistent "looping" (1310). In this overlap of symptomatic terminology, dementia itself seems to have acquired figurative properties: dementia is a "firestorm" (1308) or a 747 "coming in with no landing gear” (1309), but the apocalypse’s aftermath feels like dementia.

A broader examination of recent literature responding to culturally unintegrated cataclysms including 9/11 but also the Holocaust and other acts of catastrophic historical violence suggests that the correlation we encounter in Schneider Williams's writing between dementia and trauma is not unique. In fact, the use of dementia as a post-apocalyptic metaphor to denote both an individual and a sociocultural condition is becoming increasingly prevalent in contemporary post-trauma writing of the twenty-first century. But what exactly is the condition being represented? The answer seems to reside in how the pathology of dementia is perceived as intersecting with the symptomatology of trauma.

Trauma is characterised by a breakdown of memory, by cognitive and linguistic impairment, unimaginable from the outside and unthinkable from within: it derives from an unrecorded point of origin, an apocalypse that has already happened by the time it manifests itself, and so a missed revelation, a moment experienced and describable through the symptoms it leaves behind but never in itself. By analogy, in the case of dementia, once the condition becomes symptomatic, the apocalypse in a sense has already occurred and is manifesting itself through the erosion of memory, reasoning and language.

Unlike the effects of dementia, certainly for now, those of trauma are sometimes reversible. If a traumatised individual can be helped to retrace their steps, return to the point of apocalyptic origin and restore it to the order of memory and narrative, they may be able to resume the thread of their life story and move on. However, if the traumatic event is of a scale where it is perceived society-wide to have damaged not just individuals and institutions but, as in JeanFrançois Lyotard's seismic analogy for Auschwitz, "also the instruments used to measure earthquakes" - so our very capacity to record and relate what has happened - such recuperation may not be possible, and the trauma may cause an insurmountable breach (Lyotard 1988, 56).

The sense of coming 'after,' but therefore never really after, such an insurmountable breach can be argued to have informed, more or less consciously, every work of cultural theory or critical analysis responding directly or indirectly to the traumatic upheavals of the twentieth and twenty-first centuries, 
and particularly the Holocaust, from deconstruction to trauma theory to all recent forms of individual or collective memory theory. All seem founded on the perception of a "common pattern" in which "a disaster occurs of overwhelming, disorienting magnitude, and yet the world continues" (Berger 1999, 6), but existing structures of thought and language have been shattered in ways that "effect their own erasures from memory" and can only be "reconstructed by means of their traces, remains, survivors, and ghosts: their symptoms" (19). ${ }^{9}$ Even works of cultural theory that appear to deal with epistemological or economic developments rather than social or political trauma may exhibit these features, as James Berger proposes with regard to "theories of the modern by Foucault and of the postmodern by Lyotard, Baudrillard, and Jameson," all of which "take as their starting point some cataclysmic and irrevocable shattering or flattening or decentering that infiltrates and rearticulates all areas of culture" and which thus in effect "diagnose a post-apocalyptic condition" (Berger 1999, 31).

Over the past century, the world has seen a procession of such unintegratable events. For the majority of us alive today, our relationship to these events has been indirect, falling into broadly two categories. Either the traumatic event has been communicative, as in the case of "postmemory," in the term coined by Marianne Hirsch initially for the second-generation descendants of Holocaust survivors, whose "memory" of the past, while interpersonally transmitted, "is mediated not through recollection but through imaginative investment and creation" (Hirsch 1997, 22), though the idea of postmemory has since also been applied well beyond this context. Or, more commonly, the traumatic event has been culturally mediated as in, for instance, Alison Landsberg's notion of "prosthetic memory" in which empathetic engagement with the past through modern mass technologies allows an uninvolved individual to develop a personal response to a collective memory (2004). In Gary Weissman's more critical conceptualisation, such efforts to "feel the horror of what otherwise eludes" us are "fantasies of witnessing" (2004, 23).

As in the case of the cultural theories indicated above, both the postmemory and the prosthetic memory strands of investigation are founded on the premise of coming after an inconceivable, unspeakable traumatic upheaval that is knowable to us only in the form of secondary symptoms or mediated traces. However, in both instances, this has, paradoxically, made it possible for the aporetic founding origin of unintegratable primary trauma to be displaced by a secondary recuperative focus on the potential of forms of "after-memory" to work through its

9 For further compelling explorations of the relationship between the Holocaust and the postmodern, see also LaCapra 2001; Eaglestone 2004; Davis 2007. 
traumatic effects belatedly and vicariously. ${ }^{10}$ As Hirsch has more recently suggested with regard to postmemory: "Perhaps it is only in subsequent generations that trauma can be witnessed and worked through, by those who were not there to live it but who received its effects, belatedly, through the narratives, actions, and symptoms of the previous generation" (2001, 222).

Two decades into the twenty-first century, such recuperative impulses seem increasingly less plausible. Communicative memory of some of the greatest traumatic upheavals of the twentieth century is itself on the verge of being a thing of the past, leaving us with little sense of any retrievable origin of our post-apocalyptic "ghost world of digital data, computerized information that's manipulable, rewritable, copyable, rebootable and erasable" (Grossman 2004). In the grip of an "archive fever" (Derrida 1996 [1995]) caused, paradoxically, by the "virus of amnesia" (Huyssen 1995, 7), the information we frantically gather in this ghost world no longer seems verifiable outside of itself and can feel both self-perpetuating and self-consuming. This media-fuelled sense of living in a post-traumatic afterwards without an origin has been further reinforced in the twenty-first century by more recent sociocultural disasters, in particular acts of terrorism, that have affected virtually - or have virtually affected - the whole world but the majority of us only in mediated form, through a "firestorm" of images. This has particularly been the case with 9/11, whose perpetrators exploited the event's mediality as a staged spectacle in anticipation of its imagery replicating like a virus across the global mass media. At the same time, the nature of terrorism is such that it not only derives its traumatic force from the event itself but also projects it into the future "by the threat of the worst to come, rather than by an aggression that is 'over and done with"” (Derrida 2003, 97), and so by opening up a wound that "remains open by our terror before the future and not only the past" (96). This is not trauma that can be worked through in any conventional sense. Rather, it seems to instate an experience of history or temporality as a form of aftermath at once symptomatic and ominous.

Living in such a post-apocalyptic pre-apocalypse is an existence in "latency," to borrow a phrase recently applied by Hans Ulrich Gumbrecht (2013) to the period since 1945 and into the present as a time suspended between the impossibility of leaving the catastrophic past behind and the impossibility of moving forward beyond a horizon of equally catastrophic looming inevitabilities. Post-9/11, a similar sense prompted Art Spiegelman to propose as "the twentyfirst century's dominant metaphor" the idiom "waiting for the other shoe to

10 For a more detailed investigation into the retroactive displacement of post-traumatic memory by postmemory, see Gwyer 2014, Ch. 1 . 
drop" $(2004,1)$. In the context of such apparently insurmountable latency, neither postmemory nor prosthetic memory, as forms of post-traumatic after-memory attempting to re-present and work through the past vicariously, seems to fit the bill any longer. Increasingly, we are seeing in their stead the invocation of dementia in aftermath writing: as a lived condition affecting individuals, particularly individuals who might otherwise have retained a connection to a pre-latency past, and as an analogy for the inexorable de-menting of a culture unable to recall this past unaided but also unable to stop compulsively trying to relive it in surrogate form.

In this 'shadow of no memories,' to appropriate the title of Art Spiegelman's post-9/11 graphic novel In the Shadow of No Towers - between the analeptic shadow cast by the absent memories of the past and the proleptic pall of being unable to escape them - post-apocalyptic memory appears to have progressed from postmemory to prosthetic memory to 'prosthetic amnesia,' where fantasies of witnessing may be ceding to a fear of, and perhaps a longing for, un-witnessing. In this reading, the figure of dementia appears at once as a symptom and - in the guise of an unattainable horizon of complete oblivion - as the only possible cure to our "mnemonic convulsions" (Huyssen 1995, 7).

This essay will conclude on a brief illustration of how ideas of individual and cultural remembering and forgetting are dealt with in two twenty-firstcentury works of autobiographically informed aftermath fiction. Of these, one might be deemed to fall broadly under the heading of postmemory and the other under that of prosthetic memory, though each in fact defies such categorisation. Both texts communicate a sense of latency through imagery of a fall or, rather, of falling, as an ongoing descent without origin or impact and so effectively a process of eternal suspension. They also both invoke dementia as a theme and trope to convey an experience of this existence in suspension as one of an extended 'zombified' present. However, in both cases, the primary zombified individuals in suspension are not those who have the disease but those who fear, or fail to achieve, vicarious forgetting.

\section{After postmemory: Diary of the Fall}

Michel Laub's Diary of the Fall, originally published in Portuguese as Diário da queda, is a novel about three generations of a Jewish emigrant family in Brazil, narrated by the unnamed middle-aged third-generation son who, like his father and grandfather before him, is struggling with how to remember the unrecordable (Laub 2015 [2011]). From the narrator's account, it emerges that his grandfather 
was a Holocaust survivor and former Auschwitz inmate, who, nearing the end of his life, reportedly 'lost his mind' in a manner not medically defined by the narrator. Left with nothing but "a kind of memory that comes and goes" (1., 3), the grandfather spent his last years locked in his study, committing his story as he remembered it to a series of notebooks. ${ }^{11}$ This is replicated in the experience of the narrator's father, who has been diagnosed with early-onset Alzheimer's disease and has also taken to spending hours in his study, working on a project that is structurally similar to the grandfather's. It is replicated a further time in the diary of the son, as a reflection on and of the older two generations' undertaking.

Each account represents a differently conflicted relationship with the past as it has, or has not, entered into generational memory. Of the grandfather, the representative of first-degree memory in the survivor generation, we learn that he did not like to talk or think about what had happened to him. Accordingly, the record he kept in the period approaching his death by suicide suggests that, as his mental deterioration progressed, what was starting to fail him were above all his screen memories. His diary appears as a desperate last effort to hold onto these in defiance of underlying memories resurfacing. Rather than tell his life story, the grandfather has written "a kind of encyclopaedia" $(1 ., 25)$ in short, repetitive, causally unconnected sections, painstakingly detailing how he felt the world should be rather than how it was: a treatise with "interminable entries on the ideal city, the ideal marriage, the ideal wife, the wife's pregnancy accompanied with diligence and love by the husband" (2., 25). Among all these mirror opposites of things as they were, there is not a single mention of his time in Auschwitz or what happened to the many family members he lost there. With this willed screening-out also failing him, in the end only death seems to promise true oblivion.

While the grandfather's memory affliction appears to have consisted in an inability to forget, as he finally finds himself unable to keep suppressing his experiences, the father, as a representative of the postmemory generation, suffers from having grown up in the shadow of memories he never had but tried imaginatively to reconstruct. Unlike the grandfather, who never spoke to his son about Auschwitz, the father's interactions with the narrator as he is growing up revolve around it obsessively but without his having a memory to attach to the signifier. His postmemory connection to the past means that, even before the dementia, his own belated story, "evacuated by the stories of the previous generation" (Hirsch

11 In reflection of the mental disorientation it thematises, this unpaginated book is arbitrarily divided into achronological and non-sequential paragraphs whose numeration restarts in each of the repetitive unnumbered subsections of the text. Paragraph numbers will be included in brackets in the main body of the text, followed by page numbers as would correspond to the English text's 2015 edition. 
1997, 22), is already a de-mented one, constructed around an inaccessible narrative memory. Against this backdrop, his Alzheimer's appears as an embodiment of what is already his reality: an inherited memory dis-ease, which is set to transmit itself to the next generation.

The third-generation narrator, meanwhile, is determined to resist this transmission, and yet the transmission has already begun before his narrative sets in, and it is unclear whether it really can end with him. The titular reference to a fall, which in one respect denotes a literal fall caused by the narrator, also stands for his own existence as one long metaphorical descent from an unremembered point of origin to an uncertain point of impact. The literal fall occurs when, as teenagers, the narrator and his friends are invited to the birthday party of the only non-Jewish student at their school, a boy named João, whom they have been bullying. At the party, the Jewish boys deliberately drop and seriously injure João, which sets in train a series of events leading, initially, to a friendship between the narrator and João but ultimately to an extended period of reverse bullying during which the narrator is persecuted as a Jew by the nonJewish boy and his friends in a way that he, initially, seems penitentially to have endured or even self-destructively engineered. The narrator's figurative fall, however, long precedes these events, dating back, in his mind, to before his birth, and it extends well beyond the narrator's adolescence and possibly beyond the end of the book. Its point of origin, as the narrator understands it, resides untraceably in the absent memory of the Holocaust, and, by extension, in the second generation's postmemorial response to this, which has seen the narrator raised by a father so intent on inculcating in his son the conviction that Jews must never be victimised again that, according to the narrator, this turned him into a perpetrator.

After outlining how he has spent his life since the age of fourteen trying forcibly to induce amnesia through heavy drinking in order to move on from the never known but unforgettable past, the narrator provisionally concludes his diary by declaring that the de-mented narrative of Auschwitz will end with him, and he reveals that his own account has all along been addressed to his unborn son, representative of the fourth generation, who, the narrator hopes, will be a blank slate, unencumbered by his three male ancestors' memory affliction of being simultaneously unable to remember and unable to forget: "You'll be starting from zero and you don't want to have to carry the weight of all that" (40., 182).

However, the form of the text seems to belie its intention and runs counter to the narrator's determination to move on from the past for the sake of the next generation. In the following passage, the narrator comments on the grandfather's notebooks that imagine the world as it should have been but was not: 
My grandfather filled sixteen notebooks without once saying what he felt about my father [. . .], not one word [. . .] about how life goes on after you leave a place like Auschwitz, the renewal of hope when they have a child after leaving Auschwitz, the rediscovery of joy on seeing that child growing up like a riposte to everything they saw in Auschwitz, and just the horror of knowing that someone survived Auschwitz only to waste all their free time on that sterile enterprise, on the pointless, inexplicable exercise of imagining every real phenomenon as something to be transformed into its exact opposite, to the point that all defects, all features disappear [. . .], that horror must somehow be related to Auschwitz.

(18., 53-54)

Rather than reinforce the contrast the narrator would establish between himself and his ancestors, the passage serves to highlight the parallels between them. Like theirs, the narrator's account does not capture emotional content or use any of the words whose absence he laments in the grandfather's narrative hope, joy, life - with reference to his own unborn son. The reason for this, for both, seems to be that there is no such thing as life after Auschwitz. The resulting narrative reads almost exactly like the grandfather's "sterile enterprise": the positive feelings, but also the "defects," the "features," the "characteristics," the "horror," are all empty placeholders in the narrator's text, but none more so than the obsessively repeated "Auschwitz," the narrative's main signifier without a referent.

Structurally, the narrator's account, like the grandfather's and the father's, fails to unfold as a coherent narrative with a beginning, middle and end. His repetitive, non-sequential paragraphs consist of rambling sentences that keep looping back over already covered ground. Information pertaining to his own life is overlaid with similarly constructed segments from his father's and grandfather's accounts, such that a section titled "A Few Things I Know about Myself" in fact starts by listing things he knows about his father and grandfather (and about Primo Levi) rather than himself. This, along with the absence of page numbers, undermines any sense of progression across the three generations. It also illustrates - and extends to us - the narrator's difficulties in orienting himself relative to his material and indicates his erosion of selfhood, an erosion that is reinforced in this episode by the slide in pronouns from "he" to "you" to "they" to "someone."

In all these respects, the narrator's record of his deliberately but incompletely benumbed existence itself reads like a dementia narrative, albeit only formally. If the second generation's postmemory was the construct of a memory without content, the narrator's de-mented narrative is the product of a forgetting without content, which reverses the thrust of postmemory, making it prospective as well as retrospective. Rather than represent a safely contained first-generation memory ailment imaginatively compensated for by postmemory descendants or through prosthetic memory, dementia here has come to figure 
the apparently inescapable post-traumatic condition of coming after Auschwitz when Auschwitz is not only a memory inaccessible to working through but a memory placeholder that not even Alzheimer's can erase. Even when the narrator imagines his own end, in a plane crash scenario with "me plunging through space towards the dark empty countryside where not even my teeth will be identifiable" (30., 152-153), the image, though seemingly informed by the more recent cultural trauma of 9/11, also appears to connect back to the Holocaust as a traumatic benchmark in the reference to unidentified teeth as a person's sole remains, albeit from a position of such remove that all that persists is a trace of a stock image. With the shadow of the unremembered but unforgettable past already extending beyond his own life, we cannot help but wonder whether the narrator, too, in his claim that his son will get to start from zero, is imagining the world as he thinks it should be rather than as it is.

\section{After prosthetic memory: Falling Man}

Like the non-record keepers in Diary of the Fall, the protagonists of the second text, Don DeLillo's 9/11 novel Falling Man (2011 [2007]), find themselves unable to move out of their shadow of no memories. The novel - which starts immediately after the first of the World Trade Center towers has fallen and ends just before the second collapses - depicts the aftermath experience of Keith Neudecker, a lawyer who worked in the North Tower. Keith has escaped the tower's fall but appears unable to escape his own post-traumatic falling, without a clear point of origin or conclusion, and the text as a whole reads as an extended evocation of Keith's description of making his way down the interminable tower staircase before the collapse: like "the timeless drift of the long spiral down" (137).

The image doubles up as a figure for Keith's ensuing existence in posttraumatic suspension, which in turn both reflects and is reflected in the text's main recurring trope, a falling shirt. The falling shirt is how Keith remembers what was in fact a person jumping to their death from one of the floors above him. Unable to integrate the sight of a body in a "white shirt, hand up," already "falling before he saw it" but also "gone and then he saw it" (242), his mind transforms the image into an empty item of clothing with fluttering sleeves, which haunts him as an insurmountable traumatic flashback to what was always already a screen memory (see also 4, 88, 246). Like Auschwitz in Laub's novel or like the cipher $9 / 11$ itself, the falling shirt is an unfillable empty signifier, and, like the shirt in his mind, Keith himself is now in "timeless drift" (137), caught 
between the impossibility of recovering the past and the concomitant impossibility of restoring the future.

At the same time, the falling shirt also seems to gesture towards the fallen (or adrift) state of twenty-first-century Western civilisation more broadly. Though it appears connected to Keith's experience of traumatic dissociation, the sense of a "timeless drift" (137) seems to have been at least latently present in him long before $9 / 11$. The interminable poker games he plays after 9/11 in a futile attempt to forget the unrememberable are just an intensification of his mind-numbed existence prior to the terrorist attacks. Moreover, his sense of suspended and substanceless descent is shared by a large number of other protagonists, whether or not they were direct witnesses of the terrorist attacks. This chiefly includes his estranged wife, Lianne, whose access to events resides somewhere between the personal connection of postmemory and the cultural one of prosthetic memory but whose experience is aligned with Keith's through a description of her "feeling like a skirt and blouse without a body" (23). Though Keith is more immediately traumatised by what has happened and acts as the novel's introductory focaliser, it is Lianne who represents "the book's centre of consciousness" (Greif 2007, 19). Indeed, it seems to be precisely the "mediatedness" of her exposure that makes her more broadly representative of Western existence in the aftermath of 9/11: her knowledge of events is second-hand and primarily derived from mass-media coverage.

A sense of suspended descent also characterises the couple's young son, Justin, who does not believe that the Twin Towers have collapsed because he has not seen the TV footage of it and who keeps searching the skies for more planes, "waiting for it to happen again" (72), convinced that "this time the towers will fall [. . .], they'll really come down" (102). Indeed, in his nescience of events, Justin more than any of the characters could be said to embody the majority position of the Western world. The reality of 9/11 as we know it is determined by its reproduction and is not real to us in its absence. At the same time, our access to this reality through its reproductions, or as a reproduction, renders it permanently unreal. In the absence of an accessible reality prior to the image, there also seems to be no reachable future horizon where the towers are no longer falling but have "really come down" (102).

Finally, the disembodied shirt is given simulated re-embodied form in the figure of performance artist David Janiak, known as Falling Man, who haunts Lianne throughout the text, just as the image of the falling shirt haunts Keith. Janiak's performance, which consists in his jumping from tall buildings, suspended by a harness, may be intended as a nod to those who fell from the towers to their death, but it captures above all the "empty shirt" condition irremediably afflicting a society in which screen images, in both senses of the term, have displaced 
genuine experience and memory, and it replicates the sensation of being "in stationary fall" (34) that ensues.

This is a condition particularly well illustrated by the specific cultural trauma of 9/11, the "most photographed and filmed event in history," experienced even by the majority of those directly affected largely "as a real-time documentary about 9/11" (Wetmore 2012, 57). The protagonists' individual experience of living in the fallout of an event of which they have no authentic, personal recollection merges here with the broader sense that "increasingly, we are witnessing a world without memory [. . .]. Rather than concretizing history in narrative and popular memory, culture, in its degraded commodified form, serves to induce amnesia" (Best 1995, xi-xii). In this respect, the aftermath of 9/11 in DeLillo's depiction also reads as an illustration of existence in the Baudrillardian "hyperreal" (Baudrillard 1994 [1981]), in an age of simulation where what was once real has been replaced by simulacra without prior or outside reality, such that, as in Justin's example, images precede and engender the real, and there can be no authentic memory because there is no origin or original to remember. In this convergence, the posttraumatic is hyperreal, and the hyperreal is post-traumatic.

This reading seems to be supported by the fact that DeLillo complements his leitmotif of traumatic screen memory flashbacks with that of dementia, as a trope for a more general form of memory damage that is neither sudden onset nor transient. Lianne, whose father died by suicide after an Alzheimer's diagnosis and who fears that it is only a matter of time before she herself becomes symptomatic, volunteers conducting weekly "storyline sessions" with a group of individuals in the early stages of Alzheimer's disease. In these sessions, Lianne encourages the group members to counter the blanks in their memories with narrative and write down what they remember about their lives before their minds "slide away from the adhesive friction that makes an individual possible" (30). In fact, it is Lianne herself, like Keith and other 'memory-typical' characters in the novel, who feels that her mind has come unstuck and that she has lost the plot that would enable her to pick up the thread of her life and move on. The storyline group members' dementia gestures towards this broader de-menting of a culture incapable of forming authentic memories as well as reflecting the traumatised mind unable to return to a traumatic point of origin.

Yet the comparison also makes it quite clear that, like Keith's falling shirt memory, this cultural de-mentedness is an inauthentic, and therefore irresolvable, condition: not forgetting proper but partial, prosthetic amnesia. We are told the storyline group members still succeed in "finding narratives that rolled and tumbled" (30) even as their symptoms are steadily worsening. Lianne interprets this as "a kind of protection perhaps, a gathering against the last bare state" (156), with the implication that, ultimately, all protection will fail and 
everything will be eclipsed in the face of this state. On both counts - in their initial ability to achieve narrative coherence and in their final attainment of oblivion - the group members thus demonstrate a progression that is denied those leading 'empty-shirt' existences.

Caught between an inability to remember and an inability to forget, the story of those marked by prosthetic dementia comes to read like the novel's overall plot, which reproduces the idea of a substanceless, suspended descent at a structural level. Sonia Baelo-Allué has suggested that, by the end of the text, Falling Man "comes full circle" (2012, 77), which both is and is not entirely true. Though the novel loops back to the start in the sense that it ends where it began, with Keith walking in a daze away from the South Tower that has just collapsed and the North Tower that is about to, and though it retrospectively fills in some of the content that has gone missing from Keith's traumatised memories of the day, it is questionable whether this in fact amounts to an "assimilation and reconstruction of events" that would "help readers work through" the trauma that Keith cannot (Baelo-Allué 2012, 77). The final image of the text takes us back to the falling shirt that set the scene at the outset, but the additional content provided by the thirdperson narrator on Keith's behalf towards the end signals that the image is displaced at both the start of the text and its conclusion: in both instances, it already appears out of context and chronological sequence, a flashback to an image 'originally' witnessed from inside the tower, through an office window, but which even at this moment of its first sighting was already a screen memory, unassimilated and therefore unintegratable, a surrogate doomed to remain only partially known and incompletely forgettable. Right down to its structural level, Falling Man seems to suggest that there is no way out of this existence in suspended descent with no point of origin to return to and no ground zero to reach.

\section{Conclusion}

The figurative invocation of dementia in the texts investigated in this essay seems to run counter to more recuperative trends manifested in recent postmemory, “prosthetic memory" (Landsberg 2004), or post-postmodern fiction, where the presence of dementia in a member of the 'memory generation' may appear to facilitate or legitimise a transfer of remaining recollections to, and the retroactive rescue of memory by, later generations. ${ }^{12}$ Yet even in these latter examples, the use of dementia as a narrative device is carefully qualified and at best only

12 Cf. e.g. Hacker 2003; Goldberg 2014; Richmond Mouillot 2015; Moore 2016. 
ambiguously enabling of an 'after-memory' recuperation of the past. Even here, it is often not any remaining mental content that is communicated either to later generations or to the reader but, rather, the experience of de-menting itself. Whether overcoded by a recuperative narrative or, as in the texts discussed here, in openly eroding form, the presence of dementia in such writing seems to mark a response to a broader cultural sense of existing in a state of post-apocalyptic suspension, anticipating final obliteration. Whether this inter-cataclysmic state is considered in more narrowly post-traumatic terms as an extension of a state of postmemory or prosthetic memory, as the latest instalment of a "zombie apocalypse" (Chow et al. 2016), or as life in "remission" (Frank 2003 [1995], 8), or whether it is viewed as indicative of a broader cultural "latency" (Gumbrecht 2013) in a lingering postmemory "hyperreality" (Baudrillard 1994 [1981]), dementia evoked figuratively to convey an existential condition appears as the latest in a long line of attempts to conceptualise contemporary existence as an aftermath. ${ }^{13}$ In this constellation, dementia as a figure captures the experience of coming after a memory-breaching event that effects its own erasure and defies our efforts to think and speak it, but it also conveys the impossibility of forming authentic new memories to take the place of the increasingly evacuated signifiers of past upheavals that shape our present and determine who we are, but of which we have no first-hand memories. As with earlier related metaphors, including postmemory or prosthetic memory, the choice of dementia as a motif may therefore also gesture towards an unacknowledged longing for forgetting and putting the past to rest. However, contrary to its predecessors, the image of dementia suggests that such putting to rest is impossible except in the form of self-erasing oblivion. Dementia as an aftermath condition does not mean forgetting; it means living in the shadow of forgetting.

Though indisputably, and perhaps indefensibly, problematic in their appropriation and displacement of dementia as a lived neurodegenerative condition, the figurative practices surrounding dementia, both in the metaphors we apply to it and in its metaphorical application, suggest that there may be more to our catastrophising fear of the "apocalyptic demography" (Robertson 1990) than concern for our welfare systems and care-giving capacity, and more to the "disgust and utter terror" (Behuniak 2011, 72) inspired by dementia than a vicarious response to memory erosion, inertia and loss of self as a biomedical horizon. As ever, the underlying fear is not that the 'zombies' may be coming for us. The fear is that they may already be us - or we may be them.

13 See also Pieter Vermeulen's contribution to this volume. 


\section{References}

Baelo-Allué, Sonia. “9/11 and the Psychic Trauma Novel: Don DeLillo’s Falling Man.” Atlantis 34.1 (2012): 63-79.

Ballenger, Jesse. Self, Senility, and Alzheimer's Disease in Modern America: A History. Baltimore: Johns Hopkins UP, 2006.

Ballenger, Jesse. "Framing Confusion: Dementia, Society, and History." AMA Journal of Ethics 19.7 (2017): 713-719.

Basting, Anne Davis. Forget Memory: Creating Better Lives for People with Dementia. Baltimore: Johns Hopkins UP, 2009.

Baudrillard, Jean. Simulacra and Simulation. 1981. Trans. Sheila Faria Glaser. Ann Arbor: University of Michigan Press, 1994.

Behuniak, Susan. "The Living Dead? The Construction of People with Alzheimer's Disease as Zombies." Ageing \& Society 31.1 (2011): 70-92.

Berger, James. After the End: Representations of Post-apocalypse. Minneapolis: University of Minnesota Press, 1999.

Best, Steven. The Politics of Historical Vision: Marx, Foucault, Habermas. New York: Guilford Press, 1995.

Bussian, Tyler, Asef Aziz, Charlton Meyer, Barbara Swenson, Jan van Deursen and Darren Baker. "Clearance of Senescent Glial Cells Prevents Tau-Dependent Pathology and Cognitive Decline.” Nature 562 (2018): 578-582.

Chow, Hei-Man, Kai-Hei Tse and Karl Herrup. "Senescent Neurons in the Alzheimer's Brain Kill Nearby Healthy Neurons by Blocking Their WNT Lifeline: The Continuing Saga of the Zombie Apocalypse." Alzheimer's \& Dementia 12.7 (2016): 658.

Davis, Colin. Haunted Subjects: Deconstruction, Psychoanalysis and the Return of the Dead. Basingstoke: Palgrave Macmillan, 2007.

DeLillo, Don. Falling Man: A Novel. London: Picador, 2011 [2007].

Derrida, Jacques. Archive Fever: A Freudian Impression. 1995. Trans. Erich Prenowitz. Chicago: University of Chicago Press, 1996.

Derrida, Jacques. "Autoimmunity: Real and Symbolic Suicides; A Dialogue with Jacques Derrida." Philosophy in a Time of Terror: Dialogues with Jürgen Habermas and Jacques Derrida. Ed. Giovanna Borradori. Chicago: University of Chicago Press, 2003. 85-136.

Eaglestone, Robert. The Holocaust and the Postmodern. Oxford: Oxford UP, 2004.

Edwards, Justin. "Zombie Terrorism in an Age of Global Gothic." Gothic Studies 17.2 (2015): 12-25.

Falcus, Sarah, and Katsura Sako. Contemporary Narratives of Dementia: Ethics, Ageing, Politics. New York: Routledge, 2019.

Frank, Arthur. The Wounded Storyteller: Body, Illness, and Ethics. 1995. 2nd ed. Chicago: University of Chicago Press, 2003.

George, Daniel, and Peter Whitehouse. “The War (on Terror) on Alzheimer's.” Dementia 13.1 (2014): 120-130.

Gerritsen, Debby, Jan Oyebode and Dianne Gove. "Ethical Implications of the Perception and Portrayal of Dementia." Dementia 17.5 (2018): 596-608.

Goldberg, Rita. Motherland: Growing Up with the Holocaust. London: Halban, 2014.

Greif, Mark. “Alzheimer’s America.” London Review of Books 29.13 (2007): 19-20. 
Grossman, Lev. “Amnesia the Beautiful.” Time, 21 March 2004. http://content.time.com/time/ magazine/article/0,9171,603222,00.html (24 June 2019).

Gumbrecht, Hans Ulrich. After 1945: Latency as Origin of the Present. Stanford, CA: Stanford UP, 2013.

Gwyer, Kirstin. Encrypting the Past: The German-Jewish Holocaust Novel of the First Generation. Oxford: Oxford UP, 2014.

Hacker, Katharina. Eine Art Liebe. Frankfurt am Main: Suhrkamp, 2003.

Hartung, Heike. Ageing, Gender and Illness in Anglophone Literature: Narrating Age in the Bildungsroman. New York: Routledge, 2016.

Higgs, Paul, and Chris Gilleard, eds. Ageing, Dementia and the Social Mind: Past, Present and Future Perspectives. Hoboken, NJ: Wiley Blackwell, 2017.

Hirsch, Marianne. Family Frames: Photography, Narrative, and Postmemory. Cambridge, MA: Harvard UP, 1997.

Hirsch, Marianne. "Surviving Images: Holocaust Photographs and the Work of Postmemory." Visual Culture and the Holocaust. Ed. Barbie Zelizer. London: Athlone, 2001. 214-246.

Huyssen, Andreas. Twilight Memories: Marking Time in a Culture of Amnesia. New York: Routledge, 1995.

Innes, Anthea. Dementia Studies: A Social Science Perspective. London: Sage, 2009.

Johnsrud, Brian. "Metaphorical Memories of the Medieval Crusades after 9/11." Memory Unbound: Tracing the Dynamics of Memory Studies. Ed. Lucy Bond, Stef Craps and Pieter Vermeulen. New York: Berghahn, 2017. 195-218.

LaCapra, Dominick. Writing History, Writing Trauma. Baltimore: Johns Hopkins UP, 2001. Landsberg, Alison. Prosthetic Memory: The Transformation of American Remembrance in the Age of Mass Culture. New York: Columbia UP, 2004.

Laub, Michel. Diary of the Fall. 2011. Trans. Margaret Jull Costa. London: Vintage, 2015.

Leibing, Annette, and Lawrence Cohen, eds. Thinking about Dementia: Culture, Loss, and the Anthropology of Senility. New Brunswick, NJ: Rutgers UP, 2006.

Luckhurst, Roger. Zombies: A Cultural History. London: Reaktion, 2016.

Lyotard, Jean-François. The Differend: Phrases in Dispute. 1983. Trans. Georges Van Den Abbeele. Minneapolis: University of Minnesota Press, 1988.

Moore, Liz. The Unseen World. London: Windmill, 2016.

Muntean, Nick, and Matthew Thomas Payne. "Attack of the Livid Dead: Recalibrating Terror in the Post-September 11 Zombie Film." The War on Terror and American Popular Culture: September 11 and Beyond. Ed. Andrew Schopp and Matthew B. Hill. Madison, NJ: Fairleigh Dickinson UP, 2009. 239-258.

Richmond Mouillot, Miranda. A Fifty-Year Silence: Love, War and a Ruined House in France. New York: Crown / Random House, 2015.

Robertson, Ann. "The Politics of Alzheimer's Disease: A Case Study in Apocalyptic Demography." International Journal of Health Services 20.3 (1990): 429-442.

Schmeink, Lars. Biopunk Dystopias: Genetic Engineering, Society, and Science Fiction. Liverpool: Liverpool UP, 2016.

Schneider Williams, Susan. “The Terrorist inside My Husband's Brain.” Neurology 87 (2016): 1308-1311.

Smyth, Chris. "Charities Urge Cameron to Fund War on '21st Century Plague.” Times, 10 December 2013. https://www.thetimes.co.uk/article/crisis-over-21st-century-plagueof-dementia-dfl009m5lf3 (27 May 2013).

Spiegelman, Art. In the Shadow of No Towers. New York: Pantheon, 2004. 
Stratton, Jon. “Zombie Trouble: Zombie Texts, Bare Life and Displaced People.” European Journal of Cultural Studies 14.3 (2011): 265-281.

Swinnen, Aagje, and Mark Schweda, eds. Popularizing Dementia: Public Expressions and Representations of Forgetfulness. Bielefeld: Transcript, 2015.

Weissman, Gary. Fantasies of Witnessing: Postwar Efforts to Experience the Holocaust. Ithaca, NY: Cornell UP, 2004.

Wetmore, Kevin. Post-9/11 Horror in American Cinema. London: Continuum, 2012.

Wilson, Duncan. "Quantifying the Quiet Epidemic: Diagnosing Dementia in Late 20th-Century Britain." History of the Human Sciences 27.5 (2014): 126-146.

Zeilig, Hannah. "Dementia as a Cultural Metaphor.” Gerontologist 54.2 (2014a): 258-267.

Zeilig, Hannah. "Representations of People with Dementia in the Media and in Literature." Excellence in Dementia Care: Research into Practice. Ed. Murna Downs and Barbara Bowers. 2nd ed. Maidenhead: Open UP, 2014b. 78-90.

Zimmermann, Martina. The Poetics and Politics of Alzheimer's Disease Life-Writing. London: Palgrave Macmillan, 2017a.

Zimmermann, Martina. "Alzheimer's Disease Metaphors as Mirror and Lens to the Stigma of Dementia." Literature and Medicine 35.1 (2017b): 71-97. 
